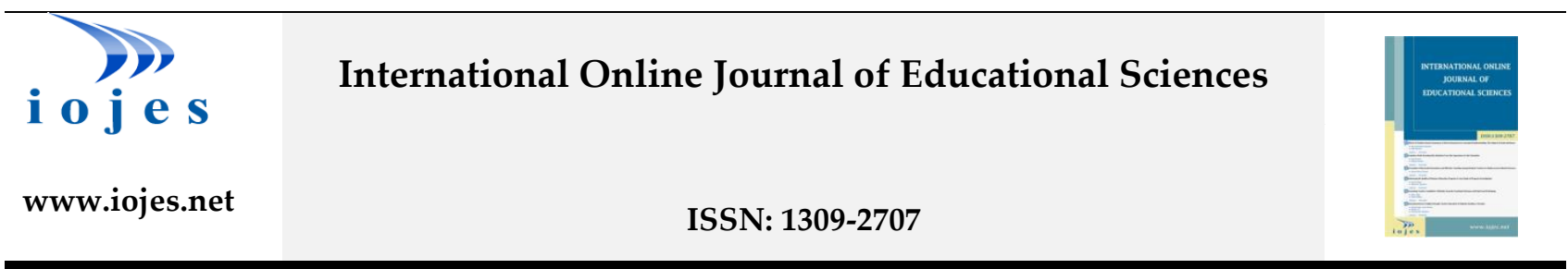

\title{
Language and Identity in the Understanding of Ali Kâmi Akyüz: The Comparison of Turkish with Western Languages
}

\author{
Research Article
}

Mete Yusuf USTABULUT ${ }^{1}$, Zeynep CETIN KOROGLU²

${ }^{1}$ Bayburt University, Faculty of Education, Department of Turkish Education, Bayburt, Turkey, ORCID: 0000-0002-8864-645X ${ }^{2}$ Aksaray University, Faculty of Education, Department of Turkish Education, Aksaray, Turkey, ORCID: 0000-0002-9456-8910

To cite this article: Ustabulut, M. Y., \& Koroglu-Cetin, Z. (2021). Language and identity in the understanding of Ali Kâmi Akyüz: The comparison of Turkish with western languages, International Online Journal of Educational Sciences, 13(1), 170-181.

\begin{tabular}{ll} 
ARTICLE INFO & ABSTRACT \\
\hline Article History: & The aim of this study was to examine Ali Kâmi Akyüz's view of language, one of the Ottoman \\
& and Republican period intellectuals, in the context of identity. The study was conducted as a \\
Received: 01.01.2020 & analysis was used for data analysis. In this context, first, Ali Kâmi Akyüz's Turkish education, \\
& foreign language education and understanding of national identity were examined. In the \\
Available online: & study, it was found that Ali Kâmi sees language as an important element of being a nation. \\
03.03.2020 & Furthermore, Ali Kâmi emphasizes the importance of affective characteristics in the education \\
& of reading and writing and recommends the question-answer technique. He doesn't believe \\
& that achieving literacy gains in a very short time is very realistic. Even though he shows a \\
& desire for simplification in language, he remains cautious about the artificial applications made \\
& in the language very quickly and collectively. He criticized the foreign language teaching \\
& policies of his period, touched on the problems in foreign language teaching and offered
\end{tabular}

${ }^{1}$ Corresponding author's address: Bayburt University, Faculty of Education

Telephone: +90 (458) 211 1154-57 - 2092

e-mail: melban111@gmail.com

DOI: https://doi.org/10.15345/iojes.2021.01.011 
solutions to these problems. Ali Kâmi suggested that understanding the language to be learned and using that language effectively is the basis of the foreign language learning and teaching process. On the other hand, Ali Kâmi emphasized that Turkish is superior to western languages in terms of logic. His view was influenced by his national sensitivity together with the First World War conditions.

(C) 2021 IOJES. All rights reserved

Keywords:

Ali Kâmi Akyüz, Foreign Language Education, Turkish Education, Turkish Education History

\section{Introduction}

Ali Kâmi [Akyüz] is one of the important historical figures of the Ottoman and Republic periods. The study examines Kâmi's views on language, mother tongue education, foreign language education and Turkish language. In order to present a more accurate and comprehensive assessment, Ali Kâmi's views on language, his world of thought, the ideas he adopted, the ideas he was influenced by and the conditions of the period he lived were also examined.

\section{Life of Ali Kâmi Akyüz (1872-1945)}

Ali Kâmi [Akyüz], the brother of poet İsmail Safa and the uncle of Peyami Safa, who was also an important writer of Turkish intellectual life, was an intellectual and educator who has served Turkish education for more than half a century. Ali Kâmi Bey, who studied at the Military Junior High School and Dârüşşafaka (secondary school for orphans) in Istanbul, was appointed as Registry Director of the Hazine-i Hassa (private treasury of the Ottoman Sultan), the Consul General in Foreign Affairs in 1908, and Kalem-i Mahsus (private secretary) in the Ministry and General Directorate of Turkish Post (PTT), and then as Principal of Dârüşşafaka, where he received his secondary education and an important human resource for the administration of PTT, on July 17, 1920. Ali Kami Bey, who held this position until 1939, became a member of parliament in the same year and died in 1945. Some of the works that Ali Kâmi, who taught French and sociology as an educator, contributed to the field of compilation, translation and literature are as follows: Mektep Âlemi,1908; Başlangıç (Alfabe), 1912; Verther, 1913,1934; Mahsus Yurd Bilgisi for primary schools, İçtimaiyat for high schools, 1928; Adolf, 1935; Kroyçer Sonat (Tolstoy), 1936; Kazaklar (Tolstoy) 1937; Pol ile Virgini (Bernarden Senpiyer) 1937; Harp ve Sulh (Tolstoy), 1938; Hintli Kulübesi, (Bernarden Senpiyer) 1939 (Ergun, 1968, p.567-568; Günay, 2000, p.354-355; Ata, 2011). Ali Kâmi Bey has also written articles in journals and newspapers such as Ulum-u İktisadiye ve İçtimaiye, Mirsad, İctihad, Gündüz, Malûmat, Servet-i Fünûn, Âşiyan, Tanin in the fields of economy, science, politics and education (Özkan, 2014; Canbaz, 2018, p.6). 


\section{Research Problem}

The problem of the study is how Ali Kâmi, an intellectual and educator of the Ottoman period, view the Turkish language against the western languages. Furthermore, Ali Kâmi's view of Turkish education and foreign language education was examined together with the problem in question. Another important matter of the study is Ali Kâmi's view of national identity and his ideology. In this context, the main problem statement and sub-problems of the study are organized as follows:

The Main Problem Statement: How is Ali Kâmi's view of the Turkish Language against Western languages?

\section{Sub-Problems:}

1) What are Ali Kâmi's views on Turkish education?

2) What are Ali Kâmi's views on foreign language education?

3) What are Ali Kâmi's views on the Turkish language?

\section{Method}

\section{Research Pattern}

The model of this study is the documentary research model. Documentary research model is used when there is no direct observation and interview opportunity. Since there was no direct observation and interview opportunity in the study, documentary pattern was chosen for the research (Yıldırım \& Şimşek, 2013, p. 218).

\section{Population-Sample of the Study}

In answering the research questions, Ali Kâmi's publications related to the research subject were reviewed. In other words, Ali Kâmi's publications on language, language education and national identity constitute the study universe of the research. Therefore, the sampling method used in the study is purposeful sampling. In this context, Ali Kâmi's articles "Language Learning 1-2" published in the Journal of Içtihad in 1913, "Logic in Languages: A comparison between Turkish and French, English, German" published in the Journal of Milli Talim ve Terbiye Cemiyeti Mecmuası and his books Mekteb âlemi: başlangıç-elifba, İctimaiyat constituted the sample of the study. 


\section{Data Collection and Data Analysis}

In this study, the document analysis technique was used to collect the data (Yildırım and Şimşek, 2013: 46; Merriam, 2013: 23). The descriptive analysis was used in the analysis of the data obtained through document analysis. In the descriptive analysis, direct quotations were made in accordance with certain themes created within the scope of the research questions and these were interpreted (Yıldırım \& Şimşek, 2013, p.256-257).

\section{Findings and Interpretation}

Ali Kâmi's assessments on language, language education and national identity are presented below in accordance with the research questions.

\section{Language, National Identity and Turkish Education in the Understanding of Ali Kâmi Akyüz}

The sociology textbook İçtimâîyyat, which was written by Ali Kâmi Bey in the republican period, provides important information about language and identity. Ali Kâmi Bey stated that he wrote this textbook by taking the Turkish society into consideration (Eryentü \& Kandal, 2016). Ali Kâmi Bey presented the elements of being a nation in the fourteenth section of the book. According to the textbook he wrote, the language is among the elements of being a nation. However, although language is not the only element to be a nation, it is the most important element for him. According to Ali Kâmi Bey, language practices implemented with establishment of the Republic of Turkey, is a reflection of national feelings. These practices were making it obligatory to read Turkish in foreign schools, to conduct transactions in Turkish in companies and to allocate more space to Turkish on shop signs. Referring to the importance of language unity, Ali Kâmi Bey mentions that Turkish children learn Greek instead of Turkish as a mother tongue in Albania under Ottoman rule. He states that this caused the Turkish children to lose their national identity and the Ottoman Empire to lose the Albanian lands. According to him, although the Ottoman Empire established a great state, it could not create a nation because it did not give importance to the Turkish language (Ali Kâmi, 1927, 15).

According to Ali Kâmi Bey, language is the most fundamental element of national identity. Ali Kâmi Bey stated the importance of translation of foreign literary works in language and literature education. He considered translation studies important not only for language education, but also for making use of Western and world civilization. According to Ali Kâmi Bey, the affective acquisition of the student is of vital importance in the acquisition of reading and writing skills in Turkish education. In this regard, he said that he prepared the book "Mekteb Âlemi: Başlangıç-Elifba" in a way that would 
increase the student's enthusiasm. In literacy education, he recommended the use of question-answer technique as a teaching technique. He criticized those who claimed to teach reading and writing in two months (Ali Kâmi, 1914, p.3-4; Ali Kâmi, 1930, p.6). Furthermore, Ali Kâmi Bey considered that language education for foreigners is a separate field of specialization, just like today. He was concerned about the phenomenon of Turkish education for foreigners, as Turkish was mandatory during the II. Constitutional Monarchy Period (Karal, 1985, p. 324). The reason for his concern was about the teaching method and the lack of well-trained teachers. If Turkish is taught to Arab children as Arabic is taught to Turkish children, no gains will be achieved (Akyüz, 1913a, p. 1725).

Ali Kâmi Bey experienced some hesitations and indecisions about the simplification of the language. In some of his articles, he stated that Arabic and Persian words add harmony to the language, so words that are not of Turkish origin are needed (Canbaz, 2018, p.35-52). On the other hand, according to Ali Kâmi, Turkishization should spread over time. He was not a supporter of total intervention in the language (Akyüz, 1918, p.26). It is necessary to look at Ali Kâmi's view of language in the Journal of İctihad, which is the medium of his westernism. Although there were fanatical Westerners among the authors of this journal, it was not possible to see a full consensus among them. Therefore, the presence of writers who benefited from Iranian poetry, Sufism and Islamic philosophy among the western writers was an important indicator of this difference (Ülken, 1979, p.207). Because, Ali Kâmi's model of modernization was a filtered Europeanization model as indicated by Celal Nuri, Rıza Tevfik and Satı Bey (Gündüz, 2010, p.177). However, Ali Kâmi Bey presented a national attitude in his literary works (Canbaz, 2018, p.35-37). Such a nourishment of ideas explains Ali Kâmi's mixed thoughts in regard with national, westernizing and partly eastern influences on language.

\section{Opinions of Ali Kâmi Akyüz Related to Turkish and Foreign Language Education}

Ali Kâmi Bey, expressed the foreign language issue again in the Journal of Gündüz and Cumhuriyet Newspaper in the 1930s (Canbaz, 2018, p.86). Ali Kâmi Akyüz discussed the current situation of foreign language teaching in his time in various articles, addressed the problems in foreign language teaching and offered solutions to these problems. In general terms, according to Ali Kâmi, students cannot receive sufficient foreign language education in French, Arabic and Persian languages. Ali Kâmi believed that the time that students spend in schools to learn foreign languages, except for those who have made their own efforts, is an unproductive time and that students cannot learn foreign language in these lessons. He based this idea on the wrong policies implemented in foreign language teaching. In his article titled Language Education, Ali Kâmi emphasizes the illogicality of taking the methods and techniques used in France to teach French children their mother 
tongue as they are and using them to teach French to Turkish children without any modifications (Ali Kâmi, 1913). Ali Kâmi's statement is as follows;

"Dictation is considered as the most important thing. Who writes the dictation correctly means that he knows French: well! To be able to write dictations, one must know the grammar well: that is also correct. Consequently, the student should learn grammar rules at the beginning and end of language education: This is wrong. Because, French children already speak French when they enter the school. So, dictation and grammar are important for the French. The first thing they need is to learn grammar rules. We can expect the same from our children, but not at the beginning of their foreign language education" (Ali Kâmi, 1913, p.1723).

Because the approaches implemented in France are for the perfection of mother tongue education. In other words, the student can already speak his mother tongue, understand what is spoken, listen and write. He stated that there is no problem in teaching and dictating the rules of the language in this case. However, applying the same method to students learning a language as a second language or as a foreign language will result in negative consequences. Ali Kâmi mentions that grammar rules and dictation are taught to students who learn foreign languages in his articles Language Education and Language Education in Schools. According to Ali Kâmi, who also taught French for many years, this approach in foreign language teaching is completely wrong. Because Ali Kâmi is aware that the student cannot use the language by memorizing only the texts in the foreign language given to them. He emphasizes the importance of students' active participation in foreign language learning (Ali Kâmi, 1913). Today, various studies demonstrated that approaches such as learning by doing, content-based learning and active learning contribute to permanent learning of the students and give students the opportunity to internalize knowledge through experience (Colvill \& Paltie, 2002; Bonwel \& Eison, 1991; Wesche \& Skehan, 2002). Considering the techniques suggested by Ali Kâmi, it is seen that they are similar to the learning and teaching approaches emphasized today. Similar to today's approaches, Ali Kâmi aimed at the student's active participation, thinking and using the language in the process of foreign language learning. Another point that Ali Kâmi emphasized in foreign language teaching is using the target language. He explains this with the following words; "While studying in Arabic and French, Turkish will not be spoken. If it is not yet time to explain this to teachers, when will it come? " (Ali Kâmi, 1913, p.1741). As it can be seen, active use of the target language in foreign language teaching during the learning and teaching process will provide students with comprehensible input (Krashen, 1988). Because one of the best ways to learn a foreign language is to 
be exposed to the target language (Hult, 2017). As noted by leading researchers in foreign language teaching, learning through language exposure will provide the necessary context and input (Al-zoubi, 2019). Similar to this view, Ali Kâmi completely opposed to the idea of teaching a foreign language with translation method. Therefore, he criticized Mehmet Fuad Köprülü for his translation works (Canbaz, 2018, p.58-62). Because he argues that a foreign language student, who is familiar with the translation method, will be constantly busy trying to translate what he hears or wants to say into the target language and his own language when speaking in a foreign language. In such a situation, it is unfortunately impossible to maintain an effective communication. He presented these views as follows; "Those who attempt to learn a language through translation can never think in that language. They absolutely have to think in their own language and translate into other language. While they speak, they are always busy translating what they say. This preoccupation prevents them from listening and understanding their interlocutors." (Ali Kâmî, 1913, p.1743). Another point that Ali Kâmi addressed that foreign teachers are assigned for foreign language teaching. But the problem he insistently emphasizes is that these teachers' knowledge of teaching foreign languages will be limited, because he stated that they only use their mother tongue very well (Ali Kâmi, 1913). As a result, Ali Kâmi touched on some problems that are encountered also in today's foreign language teaching and offered various solutions years ago. Furthermore, he emphasized that the basis of foreign language teaching and learning is to understand the target language and to use that language effectively. In today's foreign language learning policies, students are expected to understand the target language, to produce written and oral production in that language and to use it effectively (Hult, 2017). Considering the period mentioned by Ali Kâmi Akyüz, the authentic materials to be used to teach the target language and accessing natural resources from the region where the language belongs was quite limited compared to today's conditions. Therefore, it can be thought that it is not sufficient in terms of the opportunities available to those who teach the target language. In addition, the learning and teaching approaches were not as diverse as they are today, and the language was generally tried to be taught by the Grammar Translation Method (GTM) or simply by having students translated. The point to be emphasized here is the terms 'focus on form' and 'focus on meaning' (Wilkins, 1976, as cited in Long \& Robinson, 1998; Corder, 1967; Krashen, 1985). A foreign language student, who is educated through structure of the language, will know the rules of the language, but will not be able to use the language properly in terms of semantics. The language consisting of skills is perfected through practice. However, considering the conditions of Ali Kâmi's period, students learning a foreign language could not find the opportunity to travel to the countries where that language was spoken. Another important point that Ali Kâmi emphasized is that although foreign language education has been given for many years, students could not learn the language. In addition, he also mentions the shortage of hours allocated 
for foreign language teaching (Ali Kâmi, 1938). The same problem still exists today and should be addressed. However, due to various factors, it is not possible to compare the success or failure of foreign language teaching in the period of Ali Kâmi with today's foreign language teaching.

\section{Comparison of Turkish with Western Languages According to Ali Kâmi Akyüz}

According to Ali Kâmi, some differences in Turkish provide superiority to Turkish over other languages. According to Ali Kâmi (1) there is no "harf ta' rîf" (letter definition) in Turkish, (2) there is no letter that is not read in Turkish. Ali Kâmi emphasized that objects from letter definition take masculine or feminine suffixes. For example, in French, the curtain is masculine and window is feminine. In German and French languages, each object has markers, either masculine or feminine. However, there is no such rule in Turkish. These rules cause difficulties in learning the languages mentioned. In addition, the letters that are not read are not written in Turkish (Ali Kâmi, 1918). All letters read in Turkish are also written in written language and there are no letters that are not voiced. On the other hand, considering the example of French presented by Ali Kâmi, many letters that are not voiced are available in written languages such as "r", "s", "t" sounds. Another example given by Ali Kâmi is the difficulties in pronunciation in English. Because although some sounds are same in spelling, they have different pronunciations in different words (Ali Kâmi, 1918, p.24). Another example he presented is that some words are used as masculine, some as feminine and some as both masculine and feminine in German. After giving these examples, Ali Kâmi suggested that the more complex grammar rules a language has, the less logic it contains. However, he stated that there are no logical errors in Turkish (Ali Kâmi, 1918, p.25). On the other hand, he stated that it is possible to see words from Arabic, Persian and Ottoman Turkish in Turkish, and it cannot be said that it is a pure language. He considered this as a flaw, but a similar situation exists in the aforementioned Western languages. As a result, Ali Kâmi thought that there are some illogical aspects in Western languages in the context of pronunciation and grammar rules. On the other hand, he stated that some features in Turkish are also flaws.

\section{Conclusion and Discussion}

Ali Kâmi, who was around the idea of westernism, considered the language among the important elements of being a nation. He believed that the Ottoman State could not become a nation because it didn't give importance to Turkish Language. On the other hand, he was a supporter of practices implemented in the name of language nationalism in the Republic period. Even though he 
expressed a desire for simplification in the language, he remained cautious about the artificial applications carried out in the language very quickly and collectively. This stance of Ali Kâmi was a reflection of his mixed stance, which is far from a strict Westernism and includes a national attitude. He found it important to translate Western works in language education. Ali Kâmi suggested developing affective features of learners in reading and writing teaching along with question answer technique. He didn't believe that achieving literacy gains in a very short time is very realistic.

On the other hand, it can be said that Ali Kâmi had a critical perspective on foreign language teaching policies of his time. He stated that students who learn foreign languages in his time are passive recipients of knowledge and cannot internalize a foreign language. The methods and techniques used in teaching foreign languages to students were taken from western countries and used as they are. Ali Kâmi criticized these methods, which are generally based on grammar rules, dictation and translation. With his criticism, similar to today's approaches, he advocated the active participation of students as a solution to these problems. He also argued that students who learn foreign languages should use the language. He mentioned that, similar to today's foreign language teaching problems, students are not very proficient in the foreign language taught even after a long learning period. As it is known, the same problem is expressed today. However, it was not discussed in detail as it is not one of the main focuses of this study.

As stated above, Ali Kâmi compared western languages and Turkish in terms of logic in languages. His article, logic in languages, contains very important inferences and examples. According to Ali Kâmi, some unreasonable characteristics in western languages do not exist in Turkish. Even though he does not fully express it, he has the view that Turkish is superior to other languages in terms of logic. But today, every language is considered unique and it wouldn't make much sense to make a comparison between them.

Ali Kâmi argued that Turkish is superior to western languages in terms of logic. It is necessary to make sense of this reaction of Ali Kâmi both with the world of thought of the period and Ali Kâmi. First, Ali Kâmi had a relation with the Westernist ideology formed around the Journal of Içtihad. In addition, his knowledge in French and linguistics enabled him to know the West and Western languages. Ali Kâmi, who knew the Western civilization and languages, was close to the idea of Westernism on the way of modernization.

However, the emphasis on the fact that Turkish is more logical compared to Western languages comes from his national sensitivities. In the meantime, as stated before, some Westerners such as Ali Kâmi were not in favor of total Europeanization (Ülken, 1979, p.207; Gündüz, 2010, p.177; Canbaz, 
2018, p.35-37). On the other hand, it can be thought that the climate that emerged after the First World War increased the current national sensitivities and the reactivity developed in this regard. 


\section{REFERENCES}

[Akyüz], A. K. (1913a). Lisan tahsili (Maarif Nezareti'nin Nazar-1 dikkatine 1). İçtihad, 4(78). 1722-1725

[Akyüz], A. K. (1913b). Lisan tahsili (Maarif Nezareti'nin Nazar-1 dikkatine 2). İçtihad, 4(79). 1741-1744

[Akyüz], A. K. (1914). Mekteb âlemi: başlangıç-elifba. İstanbul: Kitabcı Arakel Matbaası.

[Akyüz], A. K. (1918). Lisanlarda Mantık: Türkçe ile Fransızca, İngilizce, Almanca arasında mukayese. Milli Talim ve Terbiye Cemiyeti Mecmuası. 1(4), 145-148.

[Akyüz], A. K. (1927). İçtimaiyat, İstanbul: Maârif Matbaası

[Akyüz], A. K. (1930, 6 Mayıs). Yeni anketimiz ne okuyacağız? Harf inkılâbı-Millî kûtûpane inkılâbı demek değildir - Darüşşafaka müdürü Ali Kâmi Beyin fikirleri. Vakit.

Al-zoubi, S. M. (2019). The Impact of Exposure to English Language on Language Acquisition The Impact of Exposure to English Language on Language Acquisition. Jounal of Applied Linguistics and Language Research, 5(4), 151-162.

Ata, B. (2011). “Osmanlı imparatorluğu döneminde telgrafç̧lar nasıl yetiştirildi?", Prof. Dr. Yahya Akyüz'e armağan: Türk eğitim tarihi araştırmaları, eğitim ve kültür yazıları, Ankara: PEGEM Akademi, s.283-304

Bonwell, C.C., \& Eison, J.A. (1991). Active learning: Creating excitement in theclassroom. (ERIC Document Rapor No. 1).

Canbaz, C.Y. (2018). Ali Kâmi Akyüz ve Gündüz dergisinin incelenmesi (Yayımlanmamış yüksek lisans tezi). Mimar Sinan Güzel Sanatler Üniversitesi, İstanbul.

Colvill, M. \& Pattie, I. (2002). The building blocks for scientific literarcy. Hands on science, 3, 20-22 .

Corder, S. P. (1967). The significance of learner's errors. IRAL, 5, 161-170. http://dx.doi.org/10.1515/iral.1967.5.1-4.161

Ergun, S. (1968). “Ali Kâmi Akyüz", İstanbul Ansiklopedisi, vol. I., 567-568,İstanbul: Koçu Yayınları, 1968.

Eryentü, M. ve Kandal, S. C. (2016). Woman" in high school sociology course books at Ataturk Period [Atatürk Dönemi lise sosyoloji ders kitaplarında "kadın”]. Journal of Human Sciences, 13(3), 5234-5247.

Günay, Ş.Ş. (2000). Türk parlamento tarihi: TBMM V. dönem (1939-1943), V. C. Ankara: TBMM Vakfı Yayınları.

Gündüz, M. (2010). Osmanlı mirası Cumhuriyet'in inşası-modernleşme, eğitim, kültür, ve aydınlar. Ankara: Lotus.

Gündüz, M. ve Bardak, M. (2010). Eğitimde millîlik ve milli talim ve terbiye cemiyeti mecmuası üzerine bir inceleme. Education Sciences, 5(4), 1932-1954.

Hult, F. M. (2017). Foreign language education policy on the horizon. Foreign LanguageAnnals, 51 (1), 35-45. https://doi.org/10.1111/flan.12315 
Karal, E. Z. (1985). “Tanzimat'tan sonra Türk dili sorunu”, Tanzimat'tan Cumhuriyet'e Türkiye Ansiklopedisi, C. 2, 314-332. İstanbul: İletişim yayınları.

Krashen, S. (1985). The Input Hypothesis. Oxford: Pergamon.

Krashen, S. D. (1988). Second Language Acquisition and Second Language Learning.Prentice-Hall International.

Long, M., \& Robinson, P. (1998). Focus on form: Theory, research and practice. In C. Doughty, \& J. Williams (Eds.), Focus on form in classroom second language acquisition (pp. 15- 41). Cambridge, England: Cambridge University.

Özkan, K. (2014). Türk modernleşmesinde pozitivizmin bilim algısı. Belgi Dergisi, (7), 923-951.

Ülken, H. Z. (1979).Türkiye'de çă̆daş düşünce tarihi. Ülken yayınları.

Wesche, M.B., ve Skehan, P. (2002). Communicative, task-based, and content-based language instruction. R. B. Kaplan (Haz.), The Oxford handbook of applied linguistics (ss. 227-228). Oxford, UK: Oxford University.

Yıldırım, A. ve Şimşek, H. (2013). Sosyal bilimlerde nitel araştırma yöntemleri. Ankara: Seçkin.

Merriam, S.B. (2013). Nitel araştırma-desen ve uygulama için bir rehber. (S.Turan, Çev. Ed.), Ankara: Nobel. 